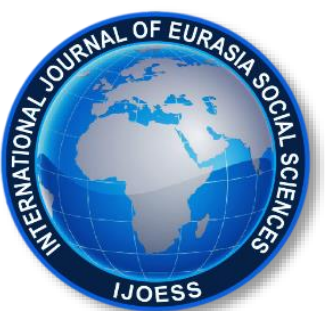

International Journal of Eurasia Social Sciences

Vol: 10, Issue: 37, pp. (968-980).

Research Article

Received: 17.05 .2019

Accepted: 22.09.2019

\title{
ORGANIZATIONAL SUPPORT AND THE ROLE OF ORGANIZATIONAL TRUST IN EMPLOYEE EMPOWERMENT
}

\author{
Fatma YILMAZ \\ Dr.Öğr.Üyesi, Erzincan Binali Yıldırım Üniversitesi, ffatmaayilmaz@gmail.com \\ ORCID: 0000-0001-8065-7245
}

\begin{abstract}
In this study, the relationship between organizational support, organizational trust and personnel empowerment was examined. In order to determine this relationship, a questionnaire was applied to the employees in a production company. The data obtained were interpreted by means of SPSS package program. In the first part of the study, literature review was conducted to explain the concepts of organizational support, organizational trust and empowerment. In the second part, the relationship between organizational support and organizational trust variables with personnel empowerment is explained. Correlation and regression analyzes were performed. According to the results of the analysis, organizational support and organizational trust variables affect personnel empowerment positively and strongly.
\end{abstract}

Keywords: Organizational support, organizational trust, employee empowerment. 


\section{INTRODUCTION}

The dynamic and uncertain environment in which businesses operate, globalization trends in the world, rapidly increasing competition and technological developments cause changes in organizational structures. With the replacement of traditional hierarchical structures in organizations with strategic human resources, concepts such as trust, support, motivation, personal development and education have become indispensable in organizational life. In order to keep up with the increasing competitive environment, organizations adopt modern management approaches consisting of teamwork instead of classical management with hierarchical order. Personnel empowerment is one of these approaches.

The main reasons for the emergence of empowerment, increased competition in organizations and the need for innovation and freedom, increased the importance of the individual and therefore the need to ensure their participation in decisions for the increase of productivity, the need to develop the strategic importance of organizations to improve the product and service to create (Çavuş, 2008: 1289).

The concept of organizational support is expressed as the general belief that employees are members of the organization that they value and contribute to their well-being. The value of the efforts put forward by employees and the perception of this value by individuals is critical for both employee satisfaction and the future of institutions (Eisenberger et al., 1986: 501; Wang and Netemeyer, 2002: 217-228). Perceived organizational support is the belief that employees value the contributions of the organization and are interested in their wellbeing (Eisenberger, et al., 1986: 501; Kraimer and Wayne, 2004: 210). Perceived organizational support affects all organizational policies. To create the desired working conditions, to provide executive support, to have an accepted reward and a sense of justice in the working environment increases personal respect, trust and personal development. In this way, employees feel less under pressure, provide more satisfaction from their jobs and perform better. There are four important factors in providing the desired organizational support; fairness, executive support and organizational reward and working conditions (Yaghoubi, et al., 2014: 316). The perception of organizational support is also defined as perceptions that employees develop depending on the value of their contribution to the organization and the degree of caring for their happiness (Taştan, et al., 2014: 122).

Employees feel respected and valued by the institution, promotion, reward and career opportunities in question, providing access to corporate information encourages the individual to perform more effectively (Rhoades and Eisenberger, 2002: 698). Organizational support consists of perceptions of employees' positive or negative behaviors from the organization. Organizational support begins the process of social change. It also meets the socio-emotional needs of employees and means greater identification and commitment to the organization, the desire to help the organization succeed, and an increase in psychological well-being (Kurtessis et al., 2015: 2).

Organizational trust, providing justice within the organization, the support of top management to employees, meeting the demands and needs of employees, increasing the level of social relations within the organization, 
the development of cooperation between employees (Neves and Caetano, 2006: 355). While trust provides greater confidence and productivity, it is also emphasized as the core and basis of all relationships (Mishra and Morrisey, 1990: 444). It is observed that organizations with high levels of trust are more successful, harmonious, innovative and dynamic organizations than organizations with low levels of trust. Organizational trust depends on job satisfaction and perceived organizational effectiveness of all employees of the organization from top to bottom. Confidence in the organization; goal formation, leadership, team spirit, organizational commitment and employee satisfaction plays an important role in organizational activities and processes such as contributing (Huff \& Kelley, 2003: 82).

Trust within the organizational structure is a form of social capital, the implicit knowledge of the organization that cannot be imitated by other organizations. Basic functions of organizational trust; Reducing transaction costs in the organization, volunteering for cooperation among members, altruistic behaviors, extra role behaviors, facilitating compliance with organizational rules and reducing conflicts. Those working in a high-trust environment support and empower organizational authorities more strongly; they are identified with the aims, norms and values of the organization. As interpersonal relationships and interaction develop, the relationship of trust may shift from cognitive to affective basis, and the parties may start to see each other as friends or colleagues (Erdem, 2003: 165). Trust ensures open communication in the organization, increases information sharing and facilitates conflict management. Trust has been proposed as a threshold condition in order to ensure the cooperation environment in organizations. In general, it is a necessary feature in enterprises in order to reduce transaction costs such as trust management costs, internalization costs (acquisitions) and social confusion. It also paves the way for collaborative innovation as an informal network (Seppanen, et al., 2007: 249).

Organizational trust; trust in managers and organizational trust are examined in two dimensions in general. Confidence in the organization and trust in managers are regarded as interrelated concepts and are called organizational trust as a whole (Tan \& Tan, 2000: 246).

Trust the manager; employees 'perceptions of their managers' support to them, their degree of trust in their promises, their perceptions that their managers deserve their position and that they are sufficient, and that their managers adopt the concept of justice and ethics (Akgündüz et al., 2016: 353). There is a strong link between the trust in the manager and the behavior of the manager to follow the orders and instructions, support him and the attachment behavior (Brockner, et al., 1997: 559). The fact that a leader is open, honest, fair and consistent in his decisions may increase the trust in the lead while contributing to the formation of trust among the employees (Ince, et al., 2004, 442).

Confidence in the organization; it reflects the belief that employees are fair and will fulfill the promises and obligations of the organization and the way employees perceive all operations and policies of the organization (Kanten, 2012: 134). An employee's perceptions of the support provided by the organization are defined as the belief that the leader will be verbal and stand behind his word, and trust is expressed as the basis of all 
organizational relations both horizontally and vertically (Mishra and Morrissey, 1990: 445). The high level of internal organizational trust decreases transaction costs by encouraging organizations to adapt to more adaptive organizational forms, strategic alliances, productive conflicts, sensitive virtual teams, and effective crisis management (Shockley, et al., 2000: 37). For a high level of trust in the organization, the organization must have a vision and purpose. Authorities and responsibilities within the organization should be clearly and comprehensibly stated (Joseph and Geroge, 2005: 8). Trust in the organization starts with trust in the manager. Employees determine the level of trust in the organization based on their interactions with the manager (Büte, 2011: 176).

The need for individuals who are able to make decisions about the organization they work for and have the ability to apply this decision without hesitation has led to the emergence of the personnel empowerment approach which is among the contemporary management theories. According to Conger and Kanungo, empowerment is the process that involves identifying the weaknesses encountered in organizations and eliminating this negativity and increasing the self-confidence of individuals (Conger and Kanungo, 1988: 478). Personnel empowerment is not to give power directly to the employees, but to reveal the power by strengthening the employee's knowledge and motivation. Personnel empowerment is seen as an encouraging tool for employees to think about the requirements of the job and to go beyond making blind orders (Akbolat, et al., 2017: 74). Empowering employees can be considered as a motivational practice aimed at improving performance by improving employee participation opportunities and increasing their participation in decision-making. Basically strengthening; It is a concept related to developing trust, building motivation, participating in decision-making process and removing any boundary between employee and senior management (Hanaysha, 2016: 300).

Personnel empowerment dimensions are meaning, competence, autonomy and influence. These dimensions are as follows (Altındiş and Özutku 2011, 166-168): Meaning size; It is the dimension that indicates that the job is meaningful for him / her. It is the dimension that expresses the harmony of the employee's values, behaviors and beliefs with their job and job roles. Competence; the competency dimension states that the employee considers himself / herself sufficient to fulfill the requirements of the job and trusts his/her knowledge, skills and abilities. Employees with high self-efficacy work harder and endeavor in the face of obstacles and problems. Employees who do not see themselves as competent, avoid situations where skills will be used and are afraid. Employees should be confident in their abilities and feel self-sufficient in this dimension. Autonomy; it means that the employee can perform his / her duties and behaviors on his / her own, make decisions, be autonomous in the working processes and have the freedom to change his / her behaviors when necessary. The employee who has the right to vote has the right and power to determine his own future. While employees feel that they have the right to choose, they lead to positive results such as self-control, creativity, initiative, durability and negative emotions. Effect; believing that the employee can make an impact in the organization. Employee are more motivated when they believe they affect organizational outcomes. When employee feel effective, they will work harder and make more effort to make an impact on the organization. 


\section{METHOD}

\section{Research Model}

This study was created with the relational screening model used to determine the presence or level of co-change between two or more variables. The study was designed to determine the effects of organizational support and organizational trust perception on employee empowerment. While the main independent variables of the research were organizational support and organizational trust (trust towards the manager and internal trust), the dependent variable was employee empowerment.

The model of the research is shown in Figure 1.

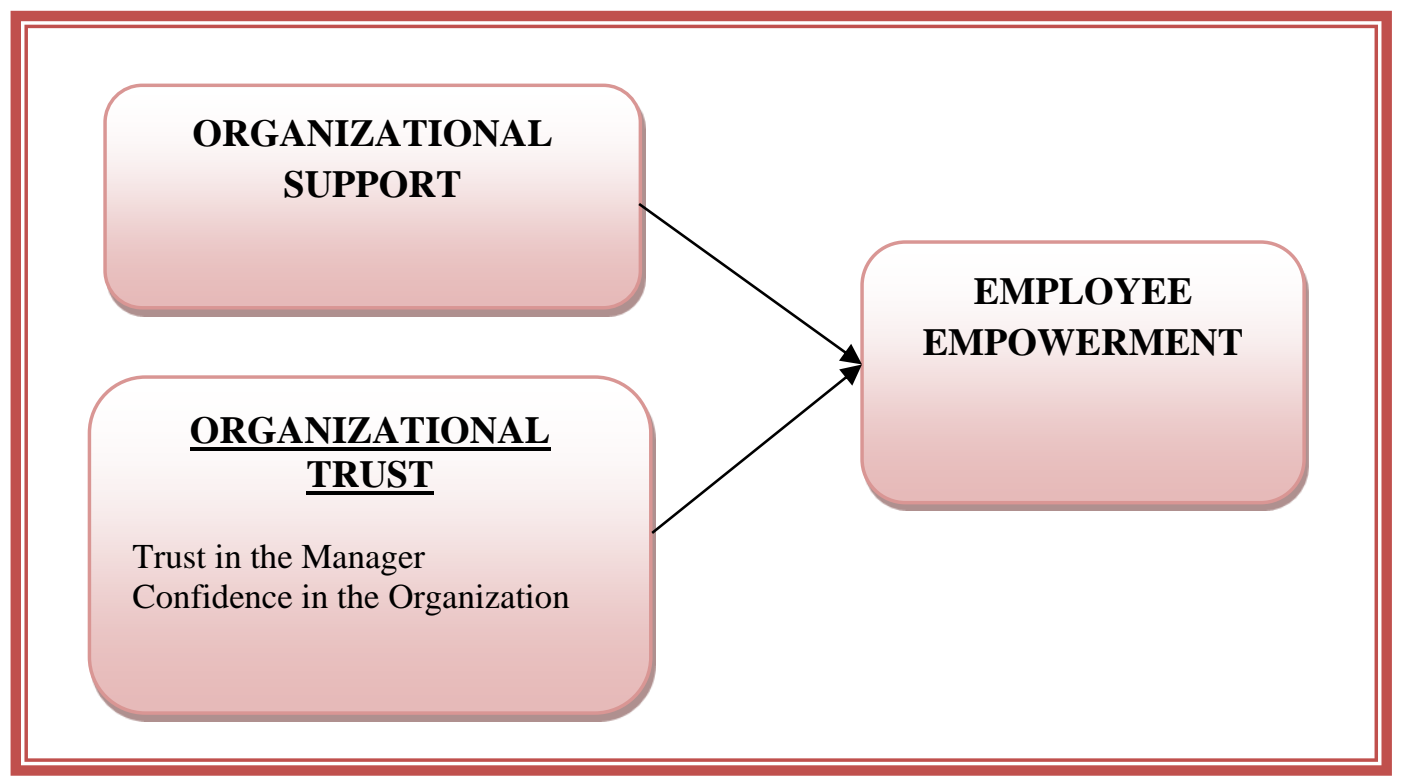

Figure 1: Research Model

The hypotheses determined in terms of addressing the purpose of the research are as follows:

H1: Organizational support has a statistically significant effect on employee empowerment.

$\mathrm{H}$ 2: Organizational trust has a statistically significant effect on employee empowerment.

$\mathrm{H} 2 \mathrm{a}$ : Trust in the manager has a statistically significant effect on employee empowerment.

$\mathrm{H} 2 \mathrm{~b}$ : Internal trust has a statistically significant effect on employee empowerment.

\section{Purpose of the research}

The purpose of this study is to explore the effect of employees' perception of organizational support and organizational trust on employee empowerment.

Within the framework of this main purpose, it is examined whether organizational support and organizational trust and sub-dimensions of trust in managers and trust within the organization affect personnel empowerment. 


\section{Research Sample and Data Collection Method}

In the study, easy sampling method was preferred as sampling method. The sample of the study consists of 230 employees of a production company operating in Tekirdağ. The questionnaire was distributed by hand and 230 valid questionnaires from 300 questionnaires were included in the study.

\section{Scales Used in Research}

The first part of the questionnaire contains questions about obtaining demographic information. In the second part, there are scales for organizational support, organizational trust and personnel empowerment respectively. The scales used were arranged as 5-point likert.

Organizational support scale; this scale was developed by Armeli-Eisenberger et al., (1998). It consists of 10 items.

Organizational trust scale; the perception of organizational trust has been evaluated in two dimensions as trust to the manager and the perception of trust within the organization.

In the first dimension, Koç and Yazıcıoğlu (2011) used Schoorman, et al., (1996), which used the scale to measure the perception of trust of employees towards managers, and the second dimension was developed by Nyhan and Marlow (1997). A 4-item scale was used.

Personnel empowerment scale; Spreitzer's (1995) "personnel empowerment scale" was used. With the 12 questions in the scale, the four sub-dimensions of empowerment, namely impact, meaning, autonomy and ability, were examined. Each sub-dimension consists of three expressions.

\section{FINDINGS}

In this part of the study, the socio-demographic variables of the participants were subjected to percentage and frequency analyzes. Correlation and regression analysis were performed to determine the relationships between organizational support, organizational trust and the trust in the manager who has sub-dimensions and intraorganizational trust sub-dimensions. The data obtained have normal distribution. For the analysis and interpretation of the data set, SPSS software was used.

Cronbach's Alpha values calculated according to the reliability analysis should be greater than 0.70 in the social sciences (Yaşar, 2014: 63). Table 1 presents the reliability analysis results of the scales used in the study.

Table 1. Reliability Analysis of Scales Used in the Research

\begin{tabular}{llll}
\hline No & Lower Dimension & Item & Cronbach's Alpha \\
\hline 1 & Organizational Support Scale & 10 &, 879 \\
\hline 2 & Organizational Trust Scale & 8 &, 825 \\
\hline 3 & Employee Empowerment Scale & 12 &, 865 \\
\hline
\end{tabular}


Cronbach's alpha value of organizational support scale; It is 0.879 . The cronbach's alpha value of the organizational trust scale; It is 0,825. The cronbach's alpha value of the employee empowerment scale; It is 0,865 . The fact that Cronbach alpha values were obtained in this way indicates that the scales provide a reliable measurement.

The socio-demographic information of the participants is given in Table 2:

Table 2. Socio-Demographic Information of Employees

\begin{tabular}{|c|c|c|c|}
\hline & & $\mathbf{N}$ & $\%$ \\
\hline \multirow[t]{3}{*}{ Age } & $18-30$ & 129 & 56,1 \\
\hline & $31-43$ & 64 & 27,8 \\
\hline & 44 years and over & 37 & 16,1 \\
\hline \multirow[t]{2}{*}{ Gender } & Female & 113 & 49,1 \\
\hline & Male & 117 & 50,9 \\
\hline \multirow[t]{4}{*}{ Education } & Primary education & 89 & 38,7 \\
\hline & High school & 75 & 32,6 \\
\hline & Associate degree & 52 & 22,6 \\
\hline & University and above & 14 & 6,1 \\
\hline \multirow[t]{2}{*}{ Marital status } & Single & 86 & 37,4 \\
\hline & Married & 144 & 62,6 \\
\hline \multirow[t]{2}{*}{ Operation type } & Shift & 152 & 66,1 \\
\hline & Non-shift & 78 & 32,6 \\
\hline \multirow[t]{4}{*}{ Total Working Time } & $1-5$ year & 134 & 58,3 \\
\hline & 6-10 year & 56 & 24,3 \\
\hline & 11-15year & 26 & 11,3 \\
\hline & 16 year and over & 14 & 6,1 \\
\hline
\end{tabular}

According to table $2 ; 49.1 \%$ was female $(n=113)$ and $50.9 \%$ was male $(n=117) ; 37.4 \%$ were single $(n=86)$ and $62.6 \%$ were married $(n=144) ; 33.9 \%$ were working without shift (continuous day / night) $(n=78)$ and $66.1 \%$ were working shifts $(n=152) ; 56.1 \%$ were in the $18-30$ age range $(n=129), 27.8 \%$ were in the $31-43$ age range $(n=64)$, and $16.1 \%$ were 44 years and over $(n=37)$ age group; $38.7 \%$ were primary school graduates $(n=89)$, $32.6 \%$ high school graduates $(n=75), 22.6 \%$ associate degree $(n=52), 6.1 \%$ i is a bachelor and a graduate (14); The duration of the study was $58.3 \%$, three were between $1-5$ years $(n=134), 24.3 \%$ were between $6-10$ years $(n=56), 11.3 \%$ were between $11-15$ years $(n) .=26), 6.1 \%$ of them were working for 15 years or more $(n=14)$.

In Table 3, the correlation analysis of organizational support, which is an independent variable, and trust and internal trust sub-dimensions of organizational trust and manager with sub-dimensions are given. 
Table 3. Correlation Analysis Results of Organizational Support, Organizational Trust and Personnel Empowerment Perception

\begin{tabular}{|c|c|c|c|c|c|c|}
\hline & & $\begin{array}{l}\text { Organization } \\
\text { al Support }\end{array}$ & $\begin{array}{l}\text { Trust the } \\
\text { Manager }\end{array}$ & $\begin{array}{l}\text { Confidence in } \\
\text { the } \\
\text { Organization }\end{array}$ & $\begin{array}{l}\text { Organizati } \\
\text { onal Trust }\end{array}$ & $\begin{array}{l}\text { Employee } \\
\text { Empowerme } \\
\text { nt }\end{array}$ \\
\hline \multirow{3}{*}{$\begin{array}{l}\text { Organizational } \\
\text { Support }\end{array}$} & Correlation & 1 & & & & \\
\hline & Sig. (p) & & & & & \\
\hline & $\mathrm{N}$ & 230 & & & & \\
\hline \multirow{3}{*}{$\begin{array}{l}\text { Trust the } \\
\text { Manager }\end{array}$} & Correlation & ,709** & 1 & & & \\
\hline & Sig. (p) &, 000 & & & & \\
\hline & $\mathrm{N}$ & 230 & 230 & & & \\
\hline \multirow{4}{*}{$\begin{array}{l}\text { Confidence in } \\
\text { the } \\
\text { Organization }\end{array}$} & Correlation &, $517^{* *}$ &, $572^{* *}$ & 1 & & \\
\hline & Sig. (p) &, 000 &, 000 & & & \\
\hline & $\mathrm{N}$ & 230 & 230 & 230 & & \\
\hline & Correlation &, $690^{* *}$ &, $882^{* *}$ &, $891^{* *}$ & 1 & \\
\hline \multirow{2}{*}{$\begin{array}{l}\text { Organizational } \\
\text { Trust }\end{array}$} & Sig. (p) & ,000 & ,000 &, 000 & & \\
\hline & $\mathrm{N}$ & 230 & 230 & 230 & 230 & \\
\hline \multirow{3}{*}{$\begin{array}{l}\text { Employee } \\
\text { Empowerment }\end{array}$} & Correlation &, $624^{* *}$ &, $631^{* *}$ &, $534^{* *}$ &, $656^{* *}$ & 1 \\
\hline & Sig. (p) &, 000 &, 000 &, 000 & ,000 & \\
\hline & $\mathrm{N}$ & 230 & 230 & 230 & 230 & 230 \\
\hline
\end{tabular}

** Correlation 0.01 is significant, $\mathrm{n}=314$

When the correlations between the variables were examined, there was a positive relationship between organizational trust dimension and organizational support dimension $\left(r=0.690^{* *}\right)$, and trust in the manager with sub-dimensions $\left(r=0.882^{* *}\right)$ and intra-organizational trust $\left(r=0.891^{* *}\right)$. This relationship is statistically significant. There was a positive correlation between employee empowerment variable and organizational support $\left(r=0.624^{* *}\right)$, trust between managers $\left(r=0.631^{* *}\right)$, intra-organizational trust $\left(r=0.534^{* *}\right)$ and organizational trust $\left(r=0.656^{* *}\right)$.

Table 4. Results of Regression Analysis of Organizational Support, Organizational Trust and Personnel Empowerment Perception

\begin{tabular}{lccccc}
\hline \multirow{1}{*}{ Model } & \multicolumn{5}{c}{ Employee Empowerment } \\
\cline { 2 - 6 } & \multicolumn{1}{c}{$\mathrm{B}$} & $\mathrm{S} . \mathrm{E}$ & $\mathrm{B}$ & $\mathrm{t}$ & $\mathrm{p}$ \\
\hline $\begin{array}{l}\text { Organizational } \\
\text { Support }\end{array}$ & 0,325 & 0,072 & 0,309 & 4,493 & 0,000 \\
\hline $\begin{array}{l}\text { Trust the } \\
\text { Manager }\end{array}$ & 0,768 & 0,188 & 0,294 & 4,095 & 0,000 \\
\hline $\begin{array}{l}\text { Confidence in the } \\
\text { Organization }\end{array}$ & 0,520 & 0,149 & 0,206 & 3,488 & 0,001 \\
\hline $\begin{array}{l}\text { Organizational } \\
\text { Trust }\end{array}$ & 0,950 & 0,072 & 0,656 & 13,130 & 0,000 \\
\hline & $\mathrm{R}=0,699$ & $\mathrm{R}^{2}=, 489$ & $\begin{array}{l}\text { Durbin- } \\
\text { Watson=1,956 }\end{array}$ & $\mathrm{F}=71,956$ & $\mathrm{p}=0,000$ \\
\hline
\end{tabular}


Table 4 shows that the results of regression. From the table 3 it is understood that there is a significant relation between. The multiple regression model between personnel empowerment and organizational support, organizational trust, executive trust and intra-organizational trust was significant $(F=71.956 ; p<0.000)$ and $48.9 \%$ of the personnel empowerment according to the determination coefficient $\left(R^{2}=0.489\right)$. It can be explained by independent variables. When the variables were examined, it was found that the dimensions of organizational support and organizational trust and its sub-dimensions had a direct relationship with employee empowerment.

As a result, $\mathrm{H} 1$ (Organizational support has a statistically significant effect on employee empowerment), $\mathrm{H} 2$ (Organizational trust has a statistically significant effect on employee empowerment), H2a (Trust in manager has a statistically significant effect on employee empowerment) and $\mathrm{H} 2 \mathrm{~b}$ ( Intra-organizational trust has a statistically significant impact on empowerment) hypotheses are accepted.

\section{CONCLUSION and DISCUSSION}

According to the results of the research, employees' perceptions of trust and support in their businesses have a strong impact on employee empowerment. Trust in managers is more effective on empowering staff than inhouse trust. It is easier to getting strength for employees, when they trust their organizations and managers also perceive support from the organization.

In the study which is coınducted by Yücel and Demirel (2012) it has been found that organizational support affected the empowerment of belonging to a group. The employee is free to know how to do the job, and the employee who feels the power trusts the management more when he / she has the authority to be aware of the opportunities and reach the opportunities. With the feeling of trust and support, the stress of the employee decreases and the feeling of burnout is replaced by motivation. Empowered employees ultimately provide productivity by connecting to work and workplace (Eren, 2014: 306).

Accordingly, there can be a two-way relationship between support, trust and empowerment.

While the employee who feels organizational support and trust gets stronger, the employee who gets stronger feels organizational support and trust more.

In addition, trust, support and empowerment provide a source of business performance improvement and sustainable competitive advantage. For this reason, it is important to provide support to managers in empowering staff and to create an atmosphere of trust within the organization.

Our study has some limitations. The study was conducted in a single province. Therefore, it is possible to show some differences with the studies to be carried out in a specific geographical region or in different sectors. However, studies with a wider sample will increase the generalizability of the results.

There are some suggestions that can be offered to researcher show want to study on this subject; 
The relations between the sub-dimensions of employees empowerment and perception of organizational trust and support can be examined. In this way, employee empowerment can be evaluated more comprehensively to generalize the results. Besides, studies on relationships between subjects, such as communication, leadership, motivation, which are thought to increase personel empowerment, whether or not these relationships scary by nationality, can be researched comparatively. 


\section{PERSONEL GÜÇLENDIRMEDE ÖRGÜTSEL DESTEK VE ÖRGÜTSEL GÜVENIN ROLÜ}

öz

Bu çalışmada örgütsel destek, örgütsel güven ve personel güçlendirme ilişkisi incelenmiştir. Bu ilişkiyi belirleyebilmek için bir üretim işletmesinde çalışanlara anket uygulaması gerçekleştirilmiştir. Elde edilen veriler SPSS paket programı ile analiz edilip yorumlanmıştır. Çalışmanın ilk bölümünde örgütsel destek, örgütsel güven ve personel güçlendirme kavramlarını açıklamaya yönelik literatür taraması yapılmıştır. İkinci bölümde örgütsel destek ve örgütsel güven değişkenlerinin personel güçlendirme ile olan ilişkileri açıklanmıştır. Bu doğrultuda korelasyon ve regresyon analizleri gerçekleştirilmiştir. Yapılan analizin sonuçlarına göre örgütsel destek ve örgütsel güven değişkenleri personel güçlendirmeyi olumlu yönde ve kuvvetli bir biçimde etkilemektedir.

Anahtar Kelimeler: Örgütsel destek, örgütsel güven, personel güçlendirme 


\section{REFERENCES}

Akbolat, M., Durmuş, A., \& Ünal, Ö. (2017). Örgütsel Erdemliliğin Personel Güçlendirmeye Etkisi ve Otantik Liderliğin Aracı Rolü. İşletme Bilimi Dergisi, 5 (2), 71-87

Akgündüz, Y., Güzel, T., \& Harman, S. (2016, Nisan). Yöneticiye Güven ve Dağıtımsal Adalet Çalışanların İşe Gömülmüşlüğünü Nasıl Etkiler? Ege Akademik Bakış, 16 (2), 351-362.

Armeli, S., Eisenberger, R., Fasolo, P., \& Lynch, P. (1998). Perceived Organizational Support and Police Performance: The Moderating Influence of Socioemotional Needs. Journal of Applied Psychology, 83(2), 288-297.

Brockner, J., Siegel, P.A., Daly, J.P., Tyler, T., \& Martin, C. (1997). When Trust Matters: The Moderating Effect of Outcome Favorability. Administrative Science Quarterly, 42(3), 558-583.

Büte, M.(2011). Etik İklim, Örgütsel Güven ve Bireysel Performans Arasındaki İlişki. Atatürk Üniversitesi İktisadi ve İdari Bilimler Dergisi, 25(1), 176-186

Conger, J. \& Kanungo, R. (1988). The Empowerment Process: Integrating Theory and Practice. The Academy of Management Review, 13(3), 471-482.

Çavuş, M. (2008). Personel Güçlendirme: İmalat Sanayi İşletmelerinde Bir Araştırma. Journal of Yasar University, 3(10), 1287-1300.

Eisenberger, R., Huntington, R., Hutchinson, S., \& Sowa, D. (1986). Perceived Organizational Support. Journal of Applied Psychology, (71), 500-507.

Erdem, F. (2003). Örgütsel Yaşamda Güven. F. Erdem, (Ed.), Sosyal Bilimlerde Güven (1. Baskı) kitap içinde (5359), Ankara: Vadi Yayınları.

Eren, M. Ş. (2014). Güçlendirme ile Nicel İşletme Performansı Arasındaki i̇lişkide Örgüte Güven ve Duygusal Bağlıığın Aracılık Etkileri. İşletme Araştırmaları Dergisi, 6(1), 303-327.

Hanaysha, J. (2016). Examining The Effects of Employee Empowerment, Teamwork, and Employee Training on Organizational Commitment. Procedia - Social and Behavioral Sciences, 229, 298-306.

Rhoades, L., \& Eisenberger, R. (2002). Perceived Organizational Support: A Review of the Literature. Journal of Applied Psychology, 87(4), 698-714.

Huff, L., \& Kelley L. (2003). Levels of Organizational Trust in Individualist Versus Collectivist Societies: A Seven Nation Study. Organization Science, 14(1), 1-4.

İnce, M., Bedük, A., \& Aydoğan, E., (2004). Örgütlerde Takım Çalışmasına Yönelik Etkin Liderlik Nitelikleri. Selçuk Üniversitesi Sosyal Bilimler Enstitüsü Dergisi, 11, 423-446.

Joseph, E. E., \& Winston, B. E. (2005). A Correlation of Servant Leadership, Leader Trust, and Organizational Trust. Leadership \& Organization Development Journal, 26(1), 6-22.

Kanten, P. (2012). İşgörenlerde İşe Adanmanın ve Proaktif Davranışların Oluşumunda Örgütsel Güven ile Örgütsel Özdeşleşmenin Rolü. Doktora Tezi, Süleyman Demirel Üniversitesi Sosyal Bilimler Enstitüsü, Isparta.

Koç, H., \& Yazıcıoğlu, İ. (2011). Yöneticiye Duyulan Güven ile İş Tatmini Arasındaki îlişki: Kamu ve Özel Sektör Karşılaştırması. Doğuş Üniversitesi Dergisi, 12(1), 46-57. 
Kraimer, M. L., \& Wayne, S. J. (2004). An Examination of Perceived Organizational Support as a Multidimensional Construct in the Context of an Expatriate Assignment. Journal of Management, $30,(2), 209-237$.

Kurtessis, N. J., Eisenberger, R., Ford, T. M., Buffardi, C. L., Stewart, A. K., \& Adis, S. C. (2015). Perceived Organizational Support: A Meta-Analytic Evaluation of Organizational Support Theory. Journal of Management, 20(10), 1-31.

Mishra, J., \& Morrissey, M. A. (1990). Trust in employee/Employer Relationships: A Survey of West Michigan Managers. Public Personnel Management, 19(4), 443- 485.

Neves, P., \& Caetano, A. (2006). Social Exchange Processes In Organizational Change: The Roles of Trust and Control. Journal of Change Management, 6(4), 351-364.

Nyhan, R. C., \& Marlowe, H. A. (1997). Development and Psychometric Properties of the Organizational Trust Inventory. Evaluation Review, 21(5), 614-635.

Seppanen, R., Blomqvist, K., \& Sundqvist, S. (2007). Measuring InterOrganizational Trust-A Critical Review of the Empirical Research in 1990-2003. Industrial Marketing Management, 36, 249 - 265.

Shockley-Zabalak, P., Kathleen, E., \& Winograd, G. (2000). Organizational Trust: What It Means, Why It Matters, Organizational Development Journal, 18(4), 35-48.

Spreitzer, G. M. (1995). Psychological Empowerment in the Workplace: Dimensions, Measurement and Validation. Academy of Management Journal 38(5), 1442-1465.

Tan, H. \& Tan, C. S. (2000). Towards The Differentiation of Trust in Supervisor And Trust in Organization. Genetic, Social And General Psychology Monographs, 126(2), 241-260.

Taştan, S., İşçi, E. \& Arslan, B. (2014). Örgütsel Destek Algısının İşe Yabancılaşma Ve Örgütsel Bağlılığa Etkisinin İncelenmesi: İstanbul Özel Hastanelerinde Bir Çalışma. Pamukkale Üniversitesi Sosyal Bilimler Enstitüsü Dergisi, 19, 121-138.

Wang, G., \& Netemeyer, R. G. (2002). The Effects of Job Autonomy, Customer Demandingness, and Trait Competitiveness on Salesperson Learning, Self-Efficacy, and Performance. Journal of the Academy of Marketing Science, 30(3), 217-228.

Yaghoubi, N. M., Pourghaz, A., Toomaj, H. G. (2014). Study of Perceived Organizational Support's Relationship With Job Burnout. International Journal of Academic Research in Business and Social Sciences, 4(6), 315-324.

Yaşar, M. (2014). İstatistiğe Yönelik Tutum Ölçeği: Geçerlilik ve Güvenilirlik Çalışması, Pamukkale Üniversitesi Eğitim Fakültesi Dergisi, 36(2), 59-75.

Yücel, İ. \& Demirel, Y. (2012). Psikolojik Güçlendirmenin Örgütsel Vatandaşlık Davranışına Etkisi Üzerine Bir Araştırma, Kocaeli Üniversitesi Sosyal Bilimler Enstitüsü Dergisi, 23, 19-48. 